\title{
Formulasi Legislative Drafting yang Ideal dalam Rangka Mewujudkan Negara Hukum yang Demokratis dan Menjunjung Nilai-Nilai Lingkungan
}

\author{
I Gusti Ayu Ketut Rachmi Handayani \\ Fakultas Hukum Universitas Sebelas Maret \\ Jl. Ir Sutami 36 A, Kentingan - Surakarta \\ ayu_igk@yahoo.com
}

\begin{abstract}
The formulations of ideal legislative drafting in the formation of environmental-based Regional Regulation is of highly essential matter to be done in a constitutional democracy. On this basis, the research problem in this research is how is the ideal formulation of legislative drafting in order to realize a democratic state of law, especially in the formation of environmental-based regional legal products? The method used in this research is a normative juridical method with qualitative analysis. As a result, this study highlights that in order to realize the ideal of a democratic state of law, the formulation of legislative drafting, especially in the formation of environmental-based regional legal products, should contain regionally-based materials of the specific condition of the area as well as further elaboration of higher legislation. The program establishment of regional regulation as instruments for program planning of Provincial Regulation or District / City Regulation arranged in a planned, integrated and systematic way, operationally lists the Regional Design Regulations which were organized based on certain method and parameters as an integral part of the national legislation system based on the Constitution of Indonesian Republic Year 1945 and the philosophy of the State.
\end{abstract}

Keywords: Formulation, legislative drafting, ideal, state of law, democratic.

\begin{abstract}
Abstrak
Formulasi legislative drafting yang ideal dalam pembentukan Peraturan Daerah berbasis lingkungan penting untuk dilakukan dalam negara demokrasi yang konstitusional. Rumusan masalah dalam penelitian ini adalah bagaimana formulasi legislative drafting yang ideal dalam rangka mewujudkan negara hukum yang demokratis khususnya dalam pembentukan produk hukum daerah berbasis lingkungan? Metode penelitian yang digunakan adalah metode penelitian yuridis normatif dengan analisis kualitatif. Hasil dari penelitian ini adalah formulasi legislative drafting yang ideal dalam rangka mewujudkan negara hukum yang demokratis khususnya dalam pembentukan produk hukum daerah berbasis lingkungan akan memuat materi muatan kondisi khusus daerah serta penjabaran lebih lanjut peraturan perundang-undangan yang lebih tinggi. Program pembentukan Perda sebagai instrumen perencanaan program pembentukan Peraturan Daerah Provinsi atau Peraturan Daerah Kabupaten/ Kota yang disusun secara terencana, terpadu, dan sistematis secara operasional memuat daftar Rancangan Peraturan Daerah yang disusun berdasarkan metode dan parameter tertentu sebagai bagian integral dari sistem peraturan perundang-undangan nasional berdasarkan Undang-Undang Dasar Negara Republik Indonesia Tahun 1945 dan Falsafah Negara.
\end{abstract}

Kata kunci: Formulasi, legislative drafting, ideal, negara hukum, demokratis 


\section{Pendahuluan}

Environmental awareness and quality are key indicators of the civilization of a nation and the essence of preserving the environment is to ensure the basic conditions for survival of both this and future generations. ${ }^{1}$ It is, however, important not to keep the domain of public reasoning confined to a given society only, especially in the case of human rights, in view of the inescapably universalist nature of these rights. ${ }^{2}$ Over the last several decades, the environmental movement has become institutionalized within the policy process, as well-organized environmental groups have gained political influence over the direction of environmental law. ${ }^{3}$ The political forces that shape the design of environmental law still tend to support more conventional forms of regulation. ${ }^{4}$

Pasal 28H ayat (1) dan Pasal 33 UUD 1945 menjadi dasar konstitusional bagi warga negara Indonesia untuk mendapatkan lingkungan hidup yang baik dan sehat. Selanjutnya, Pasal 44 UU No. 32 Tahun $2009^{5}$ tentang Perlindungan dan Pengelolaan Lingkungan Hidup menyatakan bahwa setiap penyusunan peraturan perundang-undangan pada tingkat nasional dan daerah wajib memperhatikan perlindungan fungsi lingkungan hidup dan prinsip perlindungan dan pengelolaan lingkungan hidup sesuai dengan ketentuan yang diatur dalam Undang-Undang ini. Penyusunan produk hukum daerah khususnya Peraturan Daerah (untuk selanjutnya disingkat Perda) harus memenuhi tiga aspek yaitu: aspek yuridis, filosofis dan sosiologis. Seringkali penyusunan Perda mengabaikan aspek sosiologis yaitu hukum yang berlaku di masyarakat, dan karena tidak melihat potensi dan karakteristik masyarakat, implementasi Perda banyak terganggu. Sebagian besar Perda bermasalah umumnya bertentangan dengan aturan yang lebih tinggi, terjadi tumpang tindih antara kebijakan Pusat dan Daerah. Perda memiliki kedudukan yang strategis dalam kehidupan berbangsa dan bernegara atau dengan kata lain peran Perda dalam melaksanakan urusan

1 Abdulatti et al." Variation of Environmental Awareness among the Student in Government High Schools in Solo City Indonesia", International Journal of Applied Environmental Sciences, Vol. 9. No. 5, 2014, hlm. 2701-2719.

2 Amartya Sen, "Human Rights and Capabilities", Journal of Human Development Vol. 6, No. 2, 2005, hlm. 161.

${ }^{3}$ Coglianese, C.,. "Social Movements, Law and Society: The Institutionalization of The Environmental Movement" University of Pennsylvania Law Review, 150, 2001, hlm. 85-118.

4 Keohane, N.O., Revesz, R.L., and Stavins,R.N.'”The Choice of Regulatory Instruments in Environmental Policy" Harvard Environmental Law Review 22: 1998, hlm. 313.

${ }^{5}$ Undang-Undang No. 32 Tahun 2009 tentang Perlindungan dan Pengelolaan Lingkungan Hidup. 
pemerintahan menjadi sangat besar. Kedudukan yang strategis dari Perda dalam menjalankan urusan pemerintahan dapat menjadi baik jika pembentukan Perda tersebut dilakukan dengan baik dan menjadi bumerang jika dilakukan dengan tidak baik. Jika dilihat dalam peraturan perundang-undangan, Perda memiliki posisi yang unik karena meski kedudukan Perda berada di bawah undangundang, tetapi tidak terdapat kesatuan pendapat antara para pakar mengenai siapa sebenarnya yang berwenang mengujinya. Dalam rangka pemberdayaan otonomi daerah, pemerintah pusat berwenang melakukan pembinaan dan pengawasan terhadap penyelenggaraan pemerintahan daerah sesuai dengan amanat UU No. 23 Tahun 2014 tentang Pemerintahan Daerah sebagaimana diubah beberapa kali terakhir dengan UU No. 9 Tahun 2015.6 Mengenai kedudukan Perda Kabupaten/Kota dan Perda Provinsi bisa dilihat pada Pasal 7 Undang-Undang No. 12 Tahun 2011 tentang Pembentukan Peraturan PerundangUndangan. Jenis dan hierarki peraturan perundang-undangan terdiri atas: a. UUD NRI Tahun 1945; b. Ketetapan MPR; c. UU/Perppu; d. Peraturan Pemerintah; e. Peraturan Presiden; f. Perda Provinsi; g. Perda Kabupaten/Kota.7

Kekuatan hukum suatu peraturan perundang-undangan sesuai dengan hierarki. Ini sejalan dengan asas 'kesesuaian antara jenis, hierarki, dan materi muatan', yang mengandung arti peraturan perundang-undangan harus memperhatikan materi muatan yang tepat sesuai dengan jenis dan hierarki. Dalam tataran teoritis dikenal asas lex superiori derogat legi inferiori, peraturan yang lebih tinggi mengesampingkan peraturan yang lebih rendah. Peraturan yang lebih rendah tidak boleh bertentangan dengan peraturan yang lebih tinggi. Pembentukan Produk hukum daerah diperlukan untuk menunjang terwujudnya pembentukan produk hukum daerah secara sistemik dan terkoordinasi. Optimalisasi fungsi DPRD khususnya fungsi legislasi DPRD melalui hak inisiatif merupakan hal yang mutlak diperlukan dalam rangka percepatan implementasi tata kelola pemerintahan yang baik di daerah ${ }^{8}$.

\footnotetext{
${ }^{6}$ Undang-Undang Nomor 23 Tahun 2014 tentang Pemerintahan Daerah sebagaimana telah berapa kali diubah terakhir dengan Undang-Undang Nomor 9 Tahun 2015 tentang Perubahan Kedua Atas Undang-Undang Nomor 23 Tahun 2014 tentang Pemerintahan Daerah.

7 Pasal 7 UU No. 12 Tahun 2011 tentang Pembentukan Peraturan Perundang-Undangan.

${ }^{8}$ I Gusti Ayu Ketut Rachmi Handayani, Teori dan Praktik Legal Drafting Peraturan Daerah, Cakra Books, Surakarta. 2012, hlm. 63.
} 
Legislative drafting is the process of constructing a text of legislation. The classification of a form of text of binding value as legislation is outside the scope of legislative studies: it is a constitutional issue. Legislative drafting must be distinguished from legal drafting, which involves the construction of a text used in the judicial process. And it is a narrower concept to the civil law equivalent of law-making: law-making encapsulates the whole process of conceptualization of legislation until its very implementation and thus reflects the legislative process, whereas legislative drafting reflects the drafting process only. But of course this does not mean to say that drafting is Professor Helen Xanthaki Legislative drafting: a new sub-discipline of law is born completely foreign to the legislative process. ${ }^{9}$

Negara Indonesia sebagai negara hukum bertujuan menciptakan adanya ketertiban, kemanan, keadilan dan kesejahteraan dalam kehidupan berbangsa dan bernegara. Pasal 27 ayat (1) UUD 1945 menyatakan bahwa segala warga negara bersamaan kedudukannya di dalam hukum dan pemerintahan dan wajib menjunjung hukum dan pemerintahan itu dengan tidak ada kecualinya. Untuk mewujudkan negara hukum diperlukan tata kelola pemerintahan yang baik (good governance) di segala bidang, di antaranya adalah di bidang pembentukan peraturan perundang-undangan. Tertib pembentukan peraturan perundangundangan harus dirintis sejak saat perencanaan sampai dengan pengundangannya supaya tidak kehilangan arah atau tujuan (loss purpose) sebagai negara hukum (rechtstaat). Untuk membentuk peraturan perundang-undangan yang baik, diperlukan berbagai persyaratan yang berkaitan dengan sistem, asas, tata cara penyiapan dan pembahasan, teknik, penyusunan maupun pemberlakuannya. Undang-Undang Nomor 12 Tahun 2011 adalah dasar hukum bagi pembentukan peraturan perundang-undangan baik di tingkat pusat maupun daerah. Undang-Undang ini dibentuk untuk menciptakan tertib pembentukan peraturan perundang-undangan, agar konsepsi dan perumusan normanya mantap, bulat, dan harmonis, tidak saling bertentangan, dan tumpang tindih satu sama lain. Melalui Undang-Undang tersebut, diharapkan semua lembaga yang berwenang membentuk peraturan perundang-undangan memiliki pedoman khusus yang baku dan terstandarisasi dalam proses dan metode membentuk peraturan perundang-undangan secara terencana, terpadu, dan sistematis. ${ }^{10}$

\footnotetext{
${ }^{9}$ Helen Xanthaki, "Legislative drafting: a new sub-discipline of law is born" Institute of Advanced Legal Studies Law Review University of London United Kingdom, Volume 1, Issue 1, 2013, hlm. 57-70.

${ }^{10}$ Dina M. Sirait, "Sinergitas Perencanaan Pembangunan Daerah dengan Program Pembentukan Perda dan Kaitannya dengan Pembentukan Peraturan Daerah yang Berpihak Kepada Masyarakat”, Jurnal Legislasi
} 


\section{Rumusan Masalah}

Pokok permasalahan yang diteliti dalam penelitian ini adalah bagaimana legislative drafting yang ideal dalam rangka mewujudkan negara hukum yang demokratis dan menjunjung nilai-nilai lingkungan?

\section{Tujuan Penelitian}

Tujuan penelitian ini adalah mengkaji dan menganalisis formulasi legislative drafting yang ideal dalam rangka mewujudkan negara hukum yang demokratis dan menjunjung nilai-nilai lingkungan.

\section{Metode Penelitian}

\section{Jenis dan Sifat Penelitian}

Penelitian ini menggunakan metode yuridis normatif, yaitu pendekatan yang menggunakan konsep legis positivis yang menyatakan bahwa hukum adalah identik dengan norma-norma tertulis yang dibuat dan diundangkan oleh lembaga-lembaga atau pejabat yang berwenang. Selain itu konsep ini juga memandang hukum sebagai sistem normatif yang bersifat otonom, tertutup dan terlepas dari kehidupan masyarakat.

\section{Pendekatan Penelitian}

Pendekatan penelitian menggunakan pendekatan perundang-undangan (statute approach). Dalam pendekatan perundang-undangan peneliti bukan saja melihat kepada bentuk peraturan perundang-undangan, melainkan juga menelaah materi muatannya, perlu kiranya peneliti mempelajari dasar ontologis lahirnya undang-undang, landasan filosofis undang-undang dan ratio legis dari ketentuan undang-undang. ${ }^{11}$ Di samping itu, penelitian ini juga menggunakan

Indonesia, Direktorat Jenderal Peraturan Perundang-undangan Kementerian Hukum dan HAM RI, Jakarta, 2013, hlm. 64.

11 Peter Mahmud Marzuki, Penelitian Hukum. Prenadamedia Group, Jakarta, 2014, hlm. 142. 
pendekatan konseptual oleh karena tujuan penelitian ini adalah mengkaji dan menganalisis formulasi legislative drafting yang ideal dalam rangka mewujudkan negara hukum yang demokratis dan menjunjung nilai-nilai lingkungan.

\section{Jenis dan Sumber Data}

Dalam penelitian ini data yang diperlukan meliputi data sekunder. Data sekunder dapat berupa majalah, laporan, hasil penelitian terdahulu, peraturan perundang-undangan serta publikasi lainnya. Sumber data sekunder meliputi bahan hukum primer, bahan hukum sekunder dan bahan hukum tersier.

\section{Instrumen Pengumpul Data}

Untuk data sekunder menggunakan identifikasi isi dengan metode studi kepustakaan, dimana metode ini digunakan dalam rangka memperoleh data sekunder, yaitu mengumpulkan data berupa buku-buku ilmiah yang berhubungan dengan masalah yang diteliti, dokumen-dokumen, peraturan perundangan yang sesuai dan lain sebagainya dengan membaca dan mengkajinya.

\section{Analisis Data}

Dalam penelitian ini penulis menggunakan teknik analisis kualitatif, mengingat data yang terkumpul sebagian besar merupakan data kualitatif. Teknik ini tepat bagi penelitian yang menghasilkan data yang bersifat kualitatif, yaitu data yang tidak bisa dikategorikan secara statistik kualitatif.

\section{Hasil Penelitian dan Pembahasan}

\section{Kondisi Eksisting Produk Hukum Daerah (Perda)}

The theoretical work of Wilkins has had a lasting impact on thinking about the regulation of the legal profession because it took a broader view of regulation than simply licensing, complaints and discipline, which had been the earlier focus. Wilkins proposed a four celled typology of regulation comprising disciplinary, liability, institutional, and 
legislative controls.12 Peran pemangku kepentingan (stakeholders) mulai dari anggota DPRD, alat kelengkapan DPRD, bagian hukum pemerintah daerah, satuan kerja perangkat daerah pemerintah daerah, perancang peraturan perundang-undangan, dan masyarakat, manjadi penentu dihasilkannya produk peraturan daerah yang berkualitas. Komitmen semua pihak di atas amat penting, sebab proses penyusunan peraturan perundang-undangan bukanlah hal yang mudah. Dalam menyusun peraturan daerah, eksekutif dan legislatif serta perancang seringkali dihadapkan pada permasalahan-permasalahan. Sedikitnya 1.501 Peraturan Daerah (Perda) yang dinilai memperpanjang rantai birokrasi dan menambah beban pungutan bagi investor telah dibatalkan oleh pemerintah pusat dalam rentang periode 2010-2014. Dari seluruh Perda yang dicabut itu, sebanyak 630 di antaranya merupakan perda yang berkaitan dengan pajak dan retribusi daerah yang berada dalam naungan UU No. 20 Tahun 2009 tentang Pajak Daerah dan Retribusi Daerah (PDRD) yang merevisi UU No. 34 Tahun 2000 dengan substansi yang serupa. ${ }^{13}$ Menteri Dalam Negeri Tjahjo Kumolo telah membatalkan 139 peraturan daerah terhitung sejak November 2014 hingga Mei 2015. Perda-perda yang dibatalkan tersebut dianggap bertentangan dengan undang-undang atau prinsip negara kesatuan Republik Indonesia (NKRI). ${ }^{14}$ Ketaatan Perda terhadap peraturan perundang-undangan yang lebih tinggi memang telah menjadi perhatian sejumlah kalangan. Direktorat Jenderal (Ditjen PP) Peraturan Perundang-undangan Kementerian Hukum dan HAM bahkan pernah melakukan kajian terhadap 493 Perda kabupaten/kota di 33 provinsi yang terbit pada periode 2005-2010. Hasilnya, sebagian besar penyusunan Perda tersebut belum mengikuti teknik penyusunan peraturan perundang-undangan.15 Peraturan yang baik adalah peraturan yang sesuai dengan norma yang berlaku (good norm) dan sesuai dengan proses yang berlaku (good process) yang telah diatur dalam UU No. 12 Tahun 2011. Peraturan yang baik juga mempertimbangkan nilai-nilai keadilan bagi masyarakat. Access to justice is a

12 Wilkins. D., "Who Should Regulate Lawyers?”, Harvard Law Review, 105, 1992, hlm. 801-87.

${ }^{13}$ www.kppod.org, diakses tanggal 16 Januari 2015.

14 "Sejak November 2014 hingga Mei 2015, Mendagri Batalkan 139 Perda", Kompas, 22 Juli 2015.

15 Ditjen PP Kementerian Hukum dan HAM, 2011. 
thematic of socio-legal scholars. ${ }^{16}$ Anthropological research indicated that justice as used in specific cultural settings is often described with a different word for the same aim, for example: harmony, peace and order. ${ }^{17}$

Mengingat masih banyaknya Perda yang dibatalkan oleh Pemerintah Pusat dengan alasan bertentangan dengan kepentingan umum atau peraturan yang lebih tinggi, maka langkah yang seharusnya ditempuh Pemerintah sebelum melaksanakan pengawasan represif sebaiknya juga melakukan pembinaan (evaluasi) kepada daerah, khususnya dalam pembuatan Perda secara berkelanjutan, Raperda yang kurang tepat segera dikembalikan untuk direvisi. Sehingga kemungkinan adanya kesalahan dalam pembuatan Perda dapat diminimalisir sejauh mungkin. ${ }^{18}$

\section{Penerapan Teori Legislasi dalam Pembentukan Produk Hukum}

The prevailing view, mostly within the common law world, is that drafting is a pure form art ${ }^{19}$ or a aquasi craft. ${ }^{20}$ It is this approach to the discipline that supported the mentoring style of training for drafters. ${ }^{21}$ Teori Legislasi merupakan salah satu teori yang sangat penting di dalam kerangka menganalisis tentang proses penyusunan peraturan perundang-undangan yang akan dibuat, apakah peraturan perundangundangan yang dibuat tersebut sesuai atau tidak dengan teori legislasi. Kategori untuk membantu seorang dalam pembuatan rancangan undang-undang memformulasikan suatu hipotesis penyebab yang terperinci untuk merancang undang-undang yang efektif. ${ }^{22}$ Black's Law Dictionary menyebutkan bahwa Legislative Drafting is the act of giving or enacting laws, the power to make laws, the act of legislating, preparation and enactment of laws, the making of laws via legislation, in contrast to court made laws, formulation of rule for the future, laws enacted by lawmaking

${ }^{16}$ Jacqueline A.C \& Makambombu S., "Access to Agrarian Justice in Sumba”, Law, Social Justice \& Global Development Journal, 2011, hlm. 5.

17 Moore. E., "Gender, Power and Legal Pluralism: Rajasthan, India”, American Ethnologist, 20: 3, 1993, hlm. 522-42.

${ }^{18}$ Ni'matul Huda, Problematika Pembatalan Peraturan Daerah, FH UII Press, Yogyakarta, 2010, hlm. 143.

19 B.G. Scharffs, "Law as Craft" 45 V anderbilt Law Review, 2001, hlm. 2339.

${ }^{20}$ C. Nutting, "Legislative Drafting: A Review" American Bar Association Journal, 1955, hlm. 76.

${ }^{21}$ Helen Xanthaki, "Legislative Drafting: a new sub-discipline of Law is Born", IALS Student Law Review, Vol. 1, issue 1 Autumn, 2013, hlm. 63.

22 Ann Seideman, dkk., Penyusunan Rancangan Undang-Undang Dalam Perubahan Masyarakat Yang Demokratis, diterjemahkan Johannes Usfunan, ELIPS, Jakarta, 2002, hlm. 117. 
body.23 Selanjutnya Sally Wehmeir menyebutkan Legislation is law or set of law passed by a parliament and the process of making passing laws: legislation will be difficult and will take time. ${ }^{24}$

Pasal 1 angka 2 UU No. 12 Tahun 2011 menyebutkan bahwa peraturan tertulis yang membuat norma hukum yang mengikat secara umum dan dibentuk atau ditetapkan oleh lembaga Negara atau pejabat yang berwenang melalui prosedur yang ditetapkan dalam peraturan perundang-undangan. The major studies on the subject acknowledge that the paucity of clinical legal education methods in teaching and assessment of legislative drafting is part of much larger commonwealth challenge namely: " the failure of legal education to provide adequate training on the legislative process, statutory interpretation and legislative drafting. ${ }^{25}$ Isu ini menjadi penting sejak 1983 "one of the earliest published study on the subject admitted that there is a relative paucity and variety of methods in teaching drafting in the United Kingdom ${ }^{26}$. Hal ini diperkuat oleh Xanthaki yang menulis dan mempublikasi tulisan terkait dengan legislative solutions and drafting manuals. ${ }^{27}$ Pasal 1 angka 2 UU Nomor 12 Tahun 2011 menyebutkan peraturan perundang-undangan ialah peraturan tertulis yang memuat norma hukum yang mengikat secara umum dan dibentuk atau ditetapkan oleh lembaga negara atau pejabat yang berwenang melalui prosedur yang ditetapkan dalam peraturan perundang-undangan. Di dalam Pasal 5 UU No. 12 Tahun 2011 dikenal adanya 2 macam asas yang meliputi: 1. asas pembentukan peraturan perundang-undangan yang baik; 2. asas yang berkaitan dengan materi muatan peraturan perundang-undangan. Asas pembentukan peraturan perundang-undangan yang baik meliputi: 1. kejelasan tujuan; 2. kelembagaan atau pejabat pembentuk yang tepat; 3. kesesuaian antara jenis,

\footnotetext{
hlm. 809-810.

${ }^{24}$ Sally Wehmeir, Oxford Advanced Learner's Dictionary International Student Edition, Oxford University Press, New York, 2010, hlm. 844.

${ }^{25}$ B.J. Stern, "Teaching Legislative Drafting: A Simulation Approach”, Journal of Legal Education, Vol. 38. No. 3, 1988, hlm. 391-394.

26 A.G. Donaldson, “Teaching Legislative Drafting (A Review Article)”, Statute Law Review, Vol. 4 No. 1. 1983, hlm. 179-191.

27 Helen Xanthaki, "Drafting manuals and Quality in Legislation: Positive Contribution Towards Certainty in the Law or Impediment to the Necessity for Dynamism of Rules? In Legisprudence", International Journal of the Study of Legislation, Vol. 4, No. 2, 2010, hlm. 111-128.
}

${ }^{23}$ Hendry Campbell Black, Black's Law Dictionary, West Publishing Co., United State of American, 1978, 
hierarki dan materi muatan; 4. dapat dilaksanakan; 5. kedayagunaan dan kehasilgunaan; 6. kejelasan rumusan; 7. keterbukaan. ${ }^{28}$

Di dalam Pasal 6 UU No. 12 Tahun 2011 disebutkan bahwa asas yang mencerminkan materi muatan peraturan perundang-undangan meliputi: 1. pengayoman; 2. kemanusiaan; 3. kebangsaan; 4. kekeluargaan; 5. kenusantaraan; 6. Bhineka Tunggal Ika; 7. keadilan; 8. kesamaan kedudukan dalam hukum dan pemerintahan; 9. ketertiban dan kepastian hukum; 10. keseimbangan..$^{29}$

Saldi Isra berpendapat, ada 2 fungsi legislasi yang meliputi kewenangan pembentukan undang-undang dan proses pembentukan undang-undang (law making process), yang merupakan rangkaian kegiatan yang terdiri dari: pengajuan rancangan undang-undang, pembahasan rancangan undang-undang, persetujuan rancangan undang-undang, pengesahan rancangan undang-undang, pengundangan dalam lembaran negara ${ }^{30}$.

Jimly Asshiddiqie dalam buku "Pengantar Ilmu Hukum Tata Negara" mengatakan ada 4 fungsi legislasi yaitu: 1. prakarsa pembuatan undang-undang; 2. pembahasan rancangan undang-undang; 3. persetujuan atas pengesahan rancangan undang-undang; 4 . persetujuan pengikatan atau ratifikasi atas perjanjian atau persetujuan internasional dan dokumen-dokumen hukum yang mengikat lainnya. ${ }^{31}$

Kelompok-kelompok norma hukum dalam suatu negara terdiri atas empat kelompok besar, yang meliputi: Kelompok I: staatsfundamentalnorm (norma fundamental negara), Kelompok II: staatsgrundgesezt (aturan dasar Negara), Kelompok III: formell gesezt (undang-undang formal), Kelompok IV: verordnung and autonome satzung (aturan pelaksana dan aturan otonom). ${ }^{32}$

Fauzi Ismail berpendapat bahwa partisipasi masyarakat merupakan prasyarat dan representasi dari terealisasinya pemerintahan yang demokratis. Tanpa adanya partisipasi dan hanya mengandalkan mobilisasi niscaya demokrasi

\footnotetext{
28 Pasal 5 UU No. 12 Tahun 2011 tentang Pembentukan Peraturan Perundang-Undangan.

${ }^{29}$ Pasal 6 UU No. 12 Tahun 2011 tentang Pembentukan Peraturan Perundang-Undangan.

30 Saldi Isra, Pergeseran Fungsi Legislasi Menguatnya Model Legislasi Parlementer Dalam Presidensial Indonesia, Raja Grafindo, Jakarta, 2010, hlm. 11.

31 Jimly Asshiddiqie, Pengantar Ilmu Hukum Tata Negara, Jilid 1, Sekretariat Jenderal Mahkamah Konstitusi, Jakarta, 2006, hlm. 34.

32 Maria Farida Indrati S., Ilmu Perundang-Undangan: Jenis, Fungsi dan Materi Muatan, Kanisius, Yogyakarta, 2007, hlm. 44-45.
} 
dalam sistem pemerintahan negara akan terwujud. Selain itu seiring dengan komitmen negara yang hendak melaksanakan sistem politik yang lebih demokratis, maka sudah menjadi kewajiban bagi pemerintah untuk lebih membuka diri dengan menyadari posisi perannya sebagai penyelenggara negara yang bersih untuk penguatan masyarakat sipil (civil society) dengan menegakkan prinsip-prinsip good governance yang terdiri dari 5 pilar yaitu: akuntabilitas, keterbukaan, ketaatan pada hukum, partisipasi masyarakat dan komitmen mendahulukan kepentingan bangsa dan negara. ${ }^{33}$ Public participation is an area that could potentially enhance public trust of government decision making, and thus reduce subsequent litigation. ${ }^{34}$ A good law is one that with synergy, is able of producing the regulatory results required by policy makers. ${ }^{35}$

\section{Program Pembentukan Perda}

Dalam rangka pelaksanaan dari Undang Nomor 12 Tahun 2011 yang menyatakan bahwa perencanaan penyusunan undang-undang dilakukan dalam Prolegnas (Pasal 16), sedangkan perencanaan penyusunan Peraturan Daerah Provinsi dilakukan dalam Program Pembentukan Perda Provinsi (Pasal 23). Menurut Moh Mahfud MD., politik hukum tertinggi terdapat dalam UUD NRI Tahun 1945 yang memuat arah kebijakan hukum yang harus dijalankan sesuai dengan tujuan nasional yang hendak dicapai dan berdasarkan pada Pancasila yang termaktub dalam pembukaan UUD NRI Tahun 1945. Pancasila merupakan nilai-nilai dasar yang menjadi rambu-rambu pembangunan hukum nasional, yang melahirkan empat kaidah penuntun hukum yang harus dipedomani dalam pembangunan hukum. Pertama, hukum yang dapat menjaga integrasi (keutuhan kesatuan) baik ideologi maupun teritori sesuai dengan tujuan nasional. Kedua, hukum nasional harus dibangun secara demokratis dan nomokratis, mengandung partisipasi dan menyerap aspirasi melalui mekanisme yang fair, transparan dan akuntabel. Ketiga, hukum nasional harus mampu menciptakan keadilan sosial,

\footnotetext{
${ }^{33}$ Fauzi Ismail,. Libatkan Rakyat Dalam Pengambilan Kebijakan, Forum LSM, Yogyakarta, 2005, hlm. 83.

${ }^{34}$ Tabb, W. M., "Environmental Impact Assessment in the European Community: Shaping International Norms” Tulane Review. Vol. 73, 1999, hlm. 923-960.

${ }^{35}$ L. Mader, "Evaluating the effect: a contribution to the quality of legislation" Statute Law Review, 2001, hlm. 119-131.
} 
memperpendek jurang kesenjangan. Keempat, hukum harus menjamin toleransi beragma yang berkeadaban antar pemeluknya. ${ }^{36}$

Politik hukum pasca perubahan UUD NRI Tahun 1945 juga dituangkan dalam Prolegnas (dan Program Pembentukan Perda) sebagaimana diatur dalam Undang-Undang Nomor 12 Tahun 2011. Untuk mencapai konsistensi pembuatan suatu undang-undang dengan konstitusi, harus dilakukan melalui alur politik hukum nasional yang telah diatur dengan rapi agar setiap hukum selalu mengalir dan konsisten dengan tujuan negara, sistem hukum, kaidah penuntun dan konstitusi. ${ }^{37}$ Secara garis besar Prolegnas merupakan bagian dari sistem hukum nasional. Sistem hukum nasional terdiri atas 4 (empat) sub-sistem atau unsur, yaitu budaya atau kesadaran hukum (legal culture), materi hukum (legal substance), aparatur hukum (legal apparatus) dan sarana prasarana hukum (legal structure). Pendekatan kesisteman (sistem approach) inilah yang digunakan dalam politik hukum nasional sebagaimana tertuang dalam Rencana Pembangunan Jangka Menengah (RPJM) ${ }^{38}$ Menurut pendekatan ini, yang dimaksud hukum adalah undang-undang itu sendiri dan berada dalam sub-sistem materi hukum (legal substance). Theoretical starting point for regulation is a classic paper by Shavell indicating that since information on optimal abatement techniques may often be better with government and, since, as we mentioned before, insolvency problems can arise and since for a number of reasons, a liability suit for environmental damage can never be brought, 39 regulation may be more effective to control environmental pollution than private law instruments like liability rules. ${ }^{40}$ Dalam tataran Pemerintah Pusat leading sector Kementerian yang bertanggungjawab terhadap bidang lingkungan hidup saat ini adalah Kementerian Lingkungan Hidup dan Kehutanan. Until 2001 Indonesian environmental management was an almost exclusively central government

${ }^{36}$ Mohammad Mahfud MD., Perdebatan Hukum Tata Negara Pasca Amandemen Konstitusi, LPES, Jakarta, 2007, hlm. 48 - 49.

37 Mohammad Mahfud MD., Konsistensi Materi Muatan Undang-Undang dengan Konstitusi: Antisipasi Konstitutional Review, makalah disampaikan dalam Lokakarya Program Legislasi Nasional 2009-2014, Departemen Hukum dan HAM RI, BPHN, Bandung 10-12 Juni 2009, hlm. 8 - 11

${ }^{38} \mathrm{Ibid}, \mathrm{hlm} .12$

39 Michael G. Faure, "Instruments for environmental governance: what works?" Annual Colloquium of Academy for Environmental Law of the IUCN, 2009, hlm. 7.

40 Shavell, S., "Liability for Harm versus Regulation of Safety", Journal of Legal Studies, 1984, vol. 13, hlm. 357-374. Shavell, S., "A Model of the Optimal Use of Liability and Safety Regulation", RAND Journal of Economics, 1984, vol. 15, hlm. 271-280, building further on Wittman, D.A., "Prior Regulation versus Post Liability: the Choice between Input and Output Monitoring", Journal of Legal Studies, vol. 6, 1977, hlm. $193-211$. 
affair. Environmental law and policies were made by sectoral government departments in Jakarta, notably industries, forestry and mining. Policy directives and implementing decrees were passed on to the branch offices of these departments, the so-called kantor wilayah, which were to further implement and enforce them. The state Ministry of the Environment attempted to coordinate the law and policy making process at the central level, but had little say over the sectoral Ministries. ${ }^{41}$

Untuk mewujudkan negara hukum diperlukan tatanan yang tertib (good governance) antara lain di bidang pembentukan peraturan perundang-undangan. Tertib pembentukan peraturan perundang-undangan harus dirintis sejak saat perencanaan sampai dengan pengundangannya supaya tidak kehilangan arah atau tujuan (loss purpose) sebagai negara hukum (rechtstaat). Untuk membentuk peraturan perundang-undangan yang baik, diperlukan berbagai persyaratan yang berkaitan dengan sistem, asas, tata cara penyiapan dan pembahasan, teknik, penyusunan maupun pemberlakuannya. Salah satu indikator terciptanya good governance pada tataran lokal adalah ditetapkannya sejumlah regulasi daerah yang dapat menciptakan multiplier effect. Secara normatif, pembentukan peraturan perundangundangan pada dasarnya merupakan sebuah proses sistemik yang prosesnya dimulai dari perencanaan, persiapan, teknik penyusunan, perumusan, pembahasan, pengesahan, pengundangan, dan penyebarluasan. In recent decades, political economist have called attention to the ways in which legislators and presidents can impose procedures on regulatory agencies in a strategic attempt to influence their policies. ${ }^{42}$

Berdasarkan uraian di atas, dapat dianalisis bahwa program pembentukan Perda sebagai landasan operasional pembangunan hukum di daerah melalui formulasi legislative drafting seharusnya akan dapat memproyeksikan kebutuhan hukum atau peraturan daerah, baik secara kualitatif maupun kuantitatif dengan menetapkan visi dan misi, arah kebijakan, serta indikator secara rasional. Peraturan Daerah merupakan produk hukum dan kebijakan yang menjamin kebebasan, keteraksesan, ketersediaan, kualitas. Materi muatan Peraturan Daerah termasuk Peraturan daerah di bidang lingkungan memberikan rumusan atau pengaturan yang

\footnotetext{
41 A.W. Bedner, "Introduction: Environment and Law in Indonesia" In Bedner, A,W., and N.J.A.P.B. Niessen (eds) Towards Integrated Environmental Law in Indonesia? Leiden, CNWS Publishers, 2003, hlm. 1-10.

42 McCubbins, M.D., Noll, R.G., and Weingast, B.R., "Administrative Procedures as Instruments of Political Control”, Journal of Law, Economics and Organization, 3, 1987, hlm. 243-77.
} 
berorientasi pada bantuan standar hidup (supporting living standards) dan penanggulangan ketidakadilan (reducing inequality). Orientasi rumusan tersebut akan menjadi landasan untuk membentuk kebijakan sosial sebagai upaya penanggulangan kemiskinan yang membuka peluang sosial bagi masyarakat untuk dapat mengakses pelayanan. Variation in environmental law may also be explained by differences in the institutional structures of government. One such structure is federalism, or the division of responsibility and authority between a central law maker and subsidiary governmental units. For example, although the national government has adopted most of the major environmental statutes in the U.S., much responsibilitiy for implementing these law rests with the states. In some areas of environmental law, states even retain the authority to adopt standards that differ from those adopted by the federal government. 43

Selain itu, terdapat sinergi antara lembaga yang berwenang membentuk peraturan daerah dan dapat mempercepat proses pembentukan Peraturan Daerah dengan memfokuskan kegiatan menyusun Rancangan Peraturan Daerah menurut sekala prioritas yang ditetapkan serta turut menjadi sarana pengendali dalam kegiatan pembentukan Peraturan Daerah.

\section{Kajian terhadap Asas yang Digunakan dalam Penyusunan Norma}

A first instrument, still very popular in environmental law, is the use of liability rules. They are supposed to have a preventive effect and deter potential polluters. ${ }^{44}$ In these three countries (India, Pakistan and Bangladesh) the concept of environmental justice was prompted initially by the human rights, poverty and development concerns rather than the ideas of conservation and resource protection. In South Asia, the communities can access national courts through public interest litigation (PIL) or participate in public inquiries to protect natural resources. Participation in the dicision making process could be formal or informal. 45

Untuk memahami asas-asas pembentukan peraturan perundang-undangan yang baik, dapat dimulai dari pengertian tentang asas hukum. Menurut Sudikno

43 C. Coglianese and Courcy Catherine, Environmental Regulation, The Oxford Handbook of Empirical Legal Research, 2010, hlm. 452.

44 A. Monti, "Environmental Risk: a Comparative Law and Economics Approach to Liability and Insurance", European Review of Private Law, 2001, vol. 1, hlm. 51-79.

45 Jona Razzaque in Jonas Ebbesson and Phoebe Okowa, Participatory Rights in Natural Resource Management: The Role of Communities in South Asia, Cambridge, 2009, hlm. 117-138. 
Mertokusumo asas hukum atau prinsip hukum bukanlah peraturan hukum konkrit, melainkan merupakan pikiran dasar yang umum sifatnya atau merupakan latar belakang dari peraturan konkrit yang terdapat dalam dan dibelakang setiap sistem hukum yang terjelma dalam peraturan perundangundangan dan putusan-putusan hakim yang merupakan hukum positif dan dapat dikemukakan dengan mencari sifat-sifat umum dari peraturan yang konkret tersebut. Di samping itu, legislative drafting utamanya Peraturan Daerah idealnya disusun berdasarkan nilai-nilai berbasis lingkungan. Dewees, Duff and Trebilcock hold that the large regulatory efforts to improve the environment have been met with considerable success when measured by the reduction of emissions. However, they equally stress that while environmental regulation is a determining factor in pollutant emissions and ambient concentrations, other - non-regulatory factors such as economic growth and even the weather - also influences environmental quality. ${ }^{46}$

Legislatif drafting yang ideal termasuk pembentukan Perda mencakup 2 (dua) asas hukum yang perlu diperhatikan, yaitu asas hukum umum yang khusus memberikan pedoman dan bimbingan bagi pembentukan isi peraturan dan asas hukum lainnya yang memberikan pedoman dan bimbingan bagi penuangan peraturan ke dalam bentuk dan susunannya, bagi metode pembentukannya dan bagi proses serta prosedur pembentukannya. Asas hukum yang terakhir ini dapat disebut asas peraturan perundang-undangan yang patut. Kedua asas hukum tersebut berjalan seiring berdampingan memberikan pedoman dan bimbingan serentak dalam setiap kali ada kegiatan pembentukan peraturan perundang-undangan masing-masing sesuai dengan bidangnya utamanya koheren dan sinkron dengan nilai-nilai lingkungan sehingga demokrasi lingkungan dapat terwujud.

\section{Formulasi Ideal Legislatif Drafting Berbasis Hukum Lingkungan}

Formulasi ideal legislative drafting dalam hukum lingkungan dapat diartikan bangunan desain peraturan perundangan yang sesuai dengan norma-norma yang diatur dalam payung hukum pembentukan peraturan perundang-undangan (UU

46 Dewees, D.N., Duff, D. and Trebilcock, M., Exploring the Domain of Accident Law: Taking the Facts Seriously, Oxford University Press, Oxford, 1996, hlm. 307-323. 
No. 12 Tahun 2011) sekaligus sesuai dengan payung hukum perlindungan dan pengelolaan lingkungan hidup (UU No. 32 Tahun 2009). Pasal 1 angka 10 Undang-Undang Nomor 12 Tahun 2011 menjelaskan bahwa yang dimaksud dengan Program Pembentukan Perda adalah instrumen perencanaan program pembentukan Peraturan Daerah Provinsi atau Peraturan Daerah Kabupaten/ Kota yang disusun secara terencana, terpadu dan sistematis. Program pembentukan Perda secara operasional memuat daftar Rancangan Peraturan Daerah yang disusun berdasarkan metode dan parameter tertentu sebagai bagian integral dari sistem peraturan perundang-undangan nasional berdasarkan Undang-Undang Dasar Negara Republik Indonesia Tahun 1945 dan falsasah negara. Program pembentukan Perda merupakan pedoman dan pengendali penyusunan Peraturan Daerah yang mengikat lembaga yang berwenang membentuk Peraturan Daerah, serta menjamin adanya ketepatan isi dan ketepatan prosedur. Urgensi disusunnya program pembentukan Perda berbasis hukum lingkungan antara lain: 1. memberikan gambaran obyektif tentang kebutuhan pembentukan Peraturan Daerah sekaligus menjadi potret politik hukum tentang isi hukum berbasis hukum lingkungan yang akan diatur dalam jangka waktu tertentu; 2. menetapkan skala prioritas penyusunan Rancangan Peraturan Daerah untuk jangka menengah dan pendek dengan parameter yang terukur sesuai dengan kemampuan pembentuk Peraturan Daerah berbasis hukum lingkungan; 3. menyelenggarakan koordinasi dan sinergi yang baik antar lembaga yang berwenang membentuk Peraturan Daerah berbasis hukum lingkungan; 4. menjadi sarana pengendali kegiatan pembentukan Peraturan Daerah berbasis hukum lingkungan; 5. mempercepat upaya mensejahterakan rakyat dan tertib penyelenggaraan pemerintahan di daerah secara demokratis yang menjunjung nilai-nilai hukum lingkungan.

Tujuan disusunnya program pembentukan Perda berbasis hukum lingkungan yaitu mengarahkan proses perencanaan pembentukan Perda sesuai kebutuhan pembangunan daerah, meningkatkan kualitas Perda dalam rangka mendukung pencapaian prioritas pembangunan daerah tanpa merusak lingkungan, dan meningkatkan efisiensi anggaran untuk keperluan pembentukan Peraturan Daerah dan implementasi serta penegakan hukumnya. Sebagaimana 
diatur dalam Pasal 36 ayat (3) Undang-Undang Nomor 12 Tahun 2011 bahwa “Penyusunan Program Pembentukan Perda Provinsi di lingkungan Pemerintah Daerah Provinsi dikoordinasikan oleh Biro Hukum dan dapat mengikutsertakan instansi vertikal terkait", di antara instansi vertikal terkait tersebut adalah Kantor Wilayah Hukum dan HAM di wilayah provinsi setempat. Pengaturan Mengenai Tata Cara Penyusunan dan Pengelolaan Program Pembentukan Perda secara yuridis normatif merupakan perintah dari Pasal 23 Undang-Undang Nomor 12 Tahun 2011 dinyatakan bahwa "Perencanaan penyusunan Peraturan Daerah Provinsi dilakukan dalam Program Pembentukan Perda Provinsi" sedangkan pada Pasal 39 Undang-Undang Nomor 12 Tahun 2011 disebutkan bahwa “Perencanaan penyusunan Peraturan Daerah Kabupaten/Kota dilakukan dalam Program Pembentukan Perda Kabupaten/Kota. Dengan demikian, maka dalam proses pembentukan peraturan daerah harus terlebih dahulu melalui penetapan Program Pembentukan Perda. Pada prinsipnya pembentukan Peraturan Daerah merupakan bagian dari pembangunan di daerah yang mencakup pembangunan sistem hukum daerah dengan tujuan mewujudkan tujuan daerah yang bersangkutan, yang dilakukan mulai dari perencanaan atau program secara rasional, terpadu dan sistematis. Berdasarkan uraian di atas dapat dianalisis bahwa Program Pembentukan Perda sebagai landasan operasional pembangunan hukum di daerah melalui formulasi legislative drafting seharusnya akan dapat memproyeksikan kebutuhan hukum atau peraturan daerah, baik secara kualitatif maupun kuantitatif dengan menetapkan visi dan misi, arah kebijakan, serta indikator secara rasional. Sehingga Program Pembentukan Perda mengandung kegiatan dalam kurun waktu lima tahun atau satu tahun anggaran yang memiliki nilai strategis yang akan direalisasikan sebagai bagian dari pembangunan daerah secara keseluruhan. Sebagai tahap awal dari masalah adanya kekosongan peraturan mengenai tata cara penyusunan dan pengelolaan program pembentukan Perda serta tata cara mempersiapkan raperda yang berasal dari kepala daerah, maka secepatnya segera dibentuk Peraturan Presiden yang mengaturnya. Karena dengan dibentuknya Peraturan Presiden yang mengatur mengenai tata cara penyusunan dan pengelolaan program pembentukan Perda serta tata cara mempersiapkan raperda yang berasal dari kepala daerah, 
seyogyanya pembangunan hukum di daerah terkait dengan pelaksanaan program pembentukan Perda dapat disusun secara terkoordinasi, terarah, dan terpadu yang disusun bersama oleh DPRD dan Pemerintah Daerah (Kepala Daerah) serta mengikat kepada semua kepala daerah di masing-masing daerah otonom dalam hal tata cara mempersiapkan raperda di lingkungannya.

\section{Penutup}

Formulasi legislative drafting yang ideal dalam rangka mewujudkan negara hukum yang demokratis khususnya dalam pembentukan produk hukum daerah berbasis lingkungan akan memuat materi muatan kondisi khusus daerah serta penjabaran lebih lanjut peraturan perundang-undangan yang lebih tinggi. Program pembentukan Perda sebagai instrumen perencanaan program pembentukan Peraturan Daerah Provinsi atau Peraturan Daerah Kabupaten/ Kota yang disusun secara terencana, terpadu, dan sistematis secara operasional memuat daftar Rancangan Peraturan Daerah yang disusun berdasarkan metode dan parameter tertentu sebagai bagian integral dari sistem peraturan perundangundangan nasional berdasarkan Undang-Undang Dasar Negara Republik Indonesia Tahun 1945 dan falsafah negara. Program pembentukan Perda merupakan pedoman dan pengendali penyusunan Peraturan Daerah yang mengikat lembaga yang berwenang membentuk Peraturan Daerah, serta menjamin adanya ketepatan isi, asas, norma dan ketepatan prosedur. Legislative drafting yang ideal dalam rangka mewujudkan negara hukum yang demokratis khususnya dalam pembentukan produk hukum daerah berbasis lingkungan mengarahkan proses perencanaan pembentukan Peraturan Daerah sesuai kebutuhan pembangunan daerah, meningkatkan kualitas Peraturan Daerah dalam rangka mendukung pencapaian prioritas pembangunan Daerah, dan meningkatkan efisiensi anggaran untuk keperluan pembentukan Perda dan implementasi serta penegakan hukumnya. 


\section{Daftar Pustaka}

A.C, Jacqueline \& Makambombu S., "Access to Agrarian Justice in Sumba”, Law, Social Justice E Global Development Journal, 2011.

Algonin, Abdulatti Abdullah, Ashabani Mohamed Shleag, I Gusti Ayu Ketut Rachmi Handayani, Prabang Setyono. Variation of Environmental Awareness among the Student in Government High Schools in Solo City Indonesia" International Journal of Applied Environmental Sciences". Vol. 9. No. 5, 2014.

Anonim, Direktorat Jenderal PP Kementerian Hukum dan HAM, 2011.

Asshiddiqie, Jimly, Pengantar Ilmu Hukum Tata Negara, Jilid 1, Sekretariat Jenderal Mahkamah Konstitusi, Jakarta, 2006.

Ayu Ketut Rachmi Handayani, I Gusti, Teori dan Praktik Legal Drafting Peraturan Daerah. Cakra Books, Surakarta, 2012.

Bedner, A.W., Introduction: Environment and Law in Indonesia. In Bedner, A,W., and N.J.A.P.B. Niessen (eds) Towards Integrated Environmental Law in Indonesia? Leiden, CNWS Publishers, 2003.

Black, Hendry Campbell, Black's Law Dictionary, West Publishing Co., United State of American, 1978.

Coglianese C., and Courcy Catherine, Environmental Regulation. The Oxford Handbook of Empirical Legal Research, 2010.

Coglianese, C., "Social Movements, Law and Society: The Institutionalization of The Environmental Movement", University of Pennsylvania Law Review 150, 2001.

Dewees, D.N., Duff, D. and Trebilcock, M., Exploring the Domain of Accident Law: Taking the Facts Seriously, Oxford, Oxford University Press, 1996.

Dina M. Sirait, "Sinergitas Perencanaan Pembangunan Daerah dengan Program Pembentukan Perda dan Kaitannya dengan Pembentukan Peraturan Daerah yang Berpihak Kepada Masyarakat", Jurnal Legislasi Indonesia, Direktorat Jenderal Peraturan Perundang-undangan Kementerian Hukum dan HAM RI, Jakarta, 2013.

Donaldson, A.G., “Teaching Legislative Drafting (A Review Article)”, Statute Law Review, Vol. 4 No. 1, 1983.

Ebbesson, Jonas and Phoebe Okowa, Participatory Rights in Natural Resource Management: The Role of Communities in South Asia, Cambridge, 2009.

Helen Xanthaki, "Drafting manuals and Quality in Legislation: Positive Contribution Towards Certainty in the Law or Impediment to the Necessity for Dynamism of Rules?," Legisprudence: International Journal of the Study of Legislation. Vol. 4 No. 2, 2010. 
Helen Xanthaki, "Legislative drafting: A New Sub-Discipline of Law is Born", Institute of Advanced Legal Studies Law Review University of London United Kingdom, Volume 1, Issue 1, 2013.

Huda, Ni'matul, Problematika Pembatalan Peraturan Daerah, FH UII Press, Yogyakarta, 2010.

Indrati S., Maria Farida, Ilmu Perundang-Undangan: Jenis, Fungsi dan Materi Muatan, Kanisius, Yogyakarta, 2007.

Ismail, Fauzi, Libatkan Rakyat Dalam Pengambilan Kebijakan, Forum LSM, Yogyakarta, 2005.

Isra, Saldi, Pergeseran Fungsi Legislasi Menguatnya Model Legislasi Parlementer Dalam Presidensial Indonesia, Raja Grafindo, Jakarta.

Keohane, N.O., Revesz,R.L. and Stavins,R.N, "The Choice of Regulatory Instruments in Environmental Policy", Harvard Environmental Law Review 22, 1998.

Kompas, 22 Juli 2015; “Sejak November 2014 hingga Mei 2015 Mendagri Batalkan 139 Perda".

Mader, L., "Evaluating the effect: a contribution to the quality of legislation", Statute Law Review, 2001.

Marzuki, Peter Mahmud, Penelitian Hukum, Prenadamedia Group, Jakarta, 2014.

McCubbins, M.D., Noll, R.G., and Weingast, B.R.. “Administrative Procedures as Instruments of Political Control", Journal of Law, Economics and Organization 3, 1987.

MD., Mohammad Mahfud, Konsistensi Materi Muatan Undang-Undang dengan Konstitusi: Antisipasi Konstitutional Review, makalah disampaikan dalam Lokakarya Program Legislasi Nasional 2009-2014, Departemen Hukum dan HAM RI, BPHN, Bandung 10-12 Juni 2009.

MD., Mohammad Mahfud, Perdebatan Hukum Tata Negara Pasca Amandemen Konstitusi, LPES, Jakarta, 2007.

Michael G, Faure, Instruments for environmental governance: what works? Annual Colloquium of Academy for Environmental Law of the IUCN, 2009.

Monti, A., "Environmental Risk: a Comparative Law and Economics Approach to Liability and Insurance", European Review of Private Law,Vol. 1, 2001.

Moore, E., "Gender, Power and Legal Pluralism: Rajasthan, India", American Ethnologist. 20: 3, 1993.

Nutting, C., "Legislative Drafting: A Review", American Bar Association Journal, 1955.

Scharffs, B.G., "Law as Craft", 2001. 45 Vanderbilt Law Review. 
Seideman, Ann, dkk. Penyusunan Rancangan Undang-Undang Dalam Perubahan Masyarakat Yang Demokratis, diterjemahkan Johannes Usfunan, ELIPS, Jakarta, 2002.

Sen, Amartya, "Human Rights and Capabilities", Journal of Human Development, Vol. 6, No. 2, 2005.

Shavell, S., "A Model of the Optimal Use of Liability and Safety Regulation", RAND Journal of Economics, vol. 15, 1984.

Shavell, S., "Liability for Harm versus Regulation of Safety", Journal of Legal Studies, vol. 13. 1984.

Stern, B.J., "Teaching Legislative Drafting: A Simulation Approach", Journal of Legal Education, Vol. 38. No. 3, 1988.

Tabb, W. M. "Environmental Impact Assessment in the European Community: Shaping International Norms", Tulane Review, Vol. 73, 1999.

Wehmeir, Sally, Oxford Advanced Learner's Dictionary International Student Edition, Oxford University Press, New York, 2010.

Wilkins. D, “Who Should Regulate Lawyers?” Harvard Law Review 105, 1992.

Wittman, D.A., "Prior Regulation versus Post Liability: the Choice between Input and Output Monitoring", Journal of Legal Studies, vol. 6. 1977.

www.kppod.org. Diakses tanggal 16 Januari 2015.

Peraturan Perundang-Undangan

Pasal 5 UU No. 12 Tahun 2011 Tentang Pembentukan Peraturan PerundangUndangan.

Pasal 6 UU No. 12 Tahun 2011 Tentang Pembentukan Peraturan PerundangUndangan.

Pasal 7 UU No. 12 Tahun 2011 Tentang Pembentukan Peraturan PerundangUndangan.

Undang-Undang No. 32 Tahun 2009 Tentang Perlindungan dan Pengelolaan Lingkungan Hidup.

Undang-Undang Nomor 23 Tahun 2014 tentang Pemerintahan Daerah sebagaimana telah berapa kali diubah terakhir dengan Undang-Undang Nomor 9 Tahun 2015 tentang Perubahan Kedua Atas Undang-Undang Nomor 23 Tahun 2014 tentang Pemerintahan Daerah. 